\title{
Effect of addition of coal sludge to polymeric material on thermal effects in analysis by TG/DTG/DSC methods
}

\author{
Agnieszka Kijo-Kleczkowska, Adam Gnatowski, Magdalena Szumera, \\ Henryk Otwinowski*, Dariusz Kwiatkowski, Łukasz Suchecki \\ Czestochowa University of Technology, \\ Faculty of Mechanical Engineering and Computer Science, \\ Armii Krajowej 21, 42-201 Czestochowa, Poland \\ *otwinowski@imc.pcz.czest.pl
}

\begin{abstract}
The paper presents the application of thermal analysis methods in the study of various materials: coal sludge, polymeric material and composites of a polymer with coal sludge (fraction of coal sludge in composites: 1\%, 3\% and 5\%). TG/DTG/DSC curves obtained during measurements in air atmosphere were analyzed. Polymers are used in many industries, that is why their thermal characteristics are so important. On the other hand, the mining industry, forced to supply power plants better quality fuel, must perform more thorough coal cleaning. This results in a continuous increase in waste in the form of coal sludge. The best method of disposing of these wastes is thermal utilisation (combustion and co-combustion), as well as use in composites with other materials.

The aim of the study was to demonstrate the effect of the addition of coal sludge to the polymer on the energetic effect and the rate of mass change of the material sample during the thermal process by TG/DTG/DSC methods.
\end{abstract}

\section{Introduction}

The properties of polymers depend on their structural factors as well as the conditions of their use. The structural factors include: molecular weight, the chemical structure of the macromolecules, the physical structure of the chain, crystallinity, molecular orientation and the presence of additional components. The utility conditions are: temperature, load time, pressure, type of deformation, etc. [1-7]. The properties of polymer materials can be modified by adding different types of fillers. The type and properties of the filler and polymer matrix determine the properties of the composite. Research carried out to date has enabled the development of composites with very good strength and thermal properties as well as their introduction to production [1-6].

The article presents the results of thermal tests of a polyamide modified with coal sludge, constituting waste from post-flotation enrichment of coal.

Polyamide is a thermoplastic, partly crystalline material. It is characterized by high hardness, good dimensional stability and good machinability. It is an engineering material that is used in many branches of industry. Polyamide is used, among others for the production of: gears, sliding rollers and other parts of equipment and machines, as well as in the auto- 
motive industry [2, 7-9]. The use of a filler in the form of coal sludge primarily enables utilization of the waste.

The Polish mining industry is forced to supply better coal, which causes a constant increase in waste in the form of post-flotation sludge. The best method of utilizing the sludge is to burn it in the form of a coal-water suspension, especially in a fluidized bed [10-13] and use in composites with other materials. In paper [14], the methods of thermal analysis and the results of their application in studies of various fuels: coal, biomass and sewage sludge, were reviewed.

In this paper, analysis of TG/DTG and DSC measurements was carried out for samples of polyamide, coal sludge as well as polyamide and coal sludge composites, with fractions of waste in the composite: 1,3 and $5 \%$.

In future, measurements are planned to determine the structure and properties of composites with coal sludge, which may find wider industrial use.

\section{Measurement methodology}

Polyamide 6 (PA6) under the trade name TARNAMID T-27 produced by Nitrogen Plants Tarnów was used for the tests. The filler was coal sludge (in dried form), which is a post-flotation coal waste.

The analysis of the coal sludge used in the studies is presented in Table 1.

Table 1. Analysis of coal sludge used in the studies

\begin{tabular}{|c|c|c|c|c|c|c|c|c|}
\hline $\begin{array}{c}\text { Moisture } \\
\text { content }\end{array}$ & $\begin{array}{c}\text { Volatiles } \\
\text { matter } \\
\text { content }\end{array}$ & $\begin{array}{c}\text { Ash } \\
\text { content }\end{array}$ & $\begin{array}{c}\text { Higher } \\
\text { heating } \\
\text { value } \\
\text { (HHV) }\end{array}$ & $\begin{array}{c}\text { Carbon } \\
\text { content }\end{array}$ & $\begin{array}{c}\text { Hydrogen } \\
\text { content }\end{array}$ & $\begin{array}{c}\text { Nitrogen } \\
\text { content }\end{array}$ & $\begin{array}{c}\text { Oxygen } \\
\text { content }\end{array}$ & $\begin{array}{c}\text { Total } \\
\text { sulphur } \\
\text { content }\end{array}$ \\
\hline$\%$ & $\%$ & $\%$ & $\mathrm{~kJ} / \mathrm{kg}$ & $\%$ & $\%$ & $\%$ & $\%$ & $\%$ \\
\hline 4.51 & 20.45 & 39.43 & 15024 & 40.12 & 2.82 & 0.54 & 12.11 & 0.72 \\
\hline
\end{tabular}

The polyamide, before processing, was dried in a ZELMET dryer with a kc-100/200 heat chamber, at the temperature of $80^{\circ} \mathrm{C}$, for 12 hours.

The composites were made by extrusion.

The samples for testing were injected using a KRAUSS MAFFEI KM65 - 160C1 injection molding machine, with a screw with a diameter of $30 \mathrm{~mm}$, and $\mathrm{L} / \mathrm{D}$ ratio $=23$, and a mold closing force of $650 \mathrm{kN}$ (Fig.1).

The optimal properties of the tested polyamide samples were obtained with the following injection parameters:

- injection pressure: 800 bar,

- pressing pressure: 600 bar,

- pressing time: $16 \mathrm{~s}$,

- cooling time $22 \mathrm{~s}$,

- mold temperature: $65^{\circ} \mathrm{C}$,

- nozzle temperature $240^{\circ} \mathrm{C}$.

The optimal properties of the tested composition samples of polyamide with coal sludge were obtained with the following injection parameters:

- injection pressure: 800 bar,

- pressing pressure: 600 bar, 
- pressing time: $16 \mathrm{~s}$,

- cooling time $22 \mathrm{~s}$,

- mold temperature: $65^{\circ} \mathrm{C}$,

- nozzle temperature $280^{\circ} \mathrm{C}$.

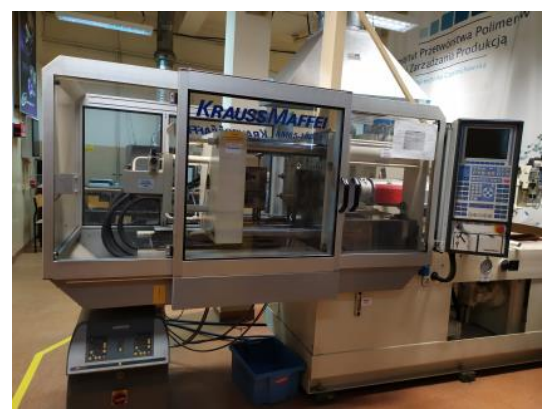

Fig. 1. KRAUSS MAFFEI KM65 - 160C1 injection molding machine

The aim of the study was to demonstrate the effect of the addition of coal sludge to the polymer on the energetic effect and the rate of mass change of the material sample, during the thermal process by TG/DTG/DSC methods.

The thermal characteristics of the samples were determined by differential scanning calorimeter (DSC) and thermogravimetric (TG-DTG) measurements conducted on an STA 449 F1 Jupiter (Netzsch) apparatus (Fig. 2), operating in the heat flux DSC mode. Five reference substances, i.e., indium, tin, bismuth, aluminum and gold were used for temperature and heat flow calibration. Samples weighing approx. $4 \mathrm{mg}$ were heated to $1100^{\circ} \mathrm{C}$ in $\mathrm{Al}_{2} \mathrm{O}_{3}$ crucibles at the rate of $10^{\circ} \mathrm{C} / \mathrm{min}$ in a dry air atmosphere. Good reproducibility of the DSCTG measurements was confirmed by repeated measurements; and was approx. $\pm 0.5^{\circ} \mathrm{C}$. All the thermal parameters were calculated using the Proteus Analysis Program (Netzsch) [15].

\section{Analysis of measurement results}

Figures 3-6 and Table 2 present the analysis of the measurement results. The addition of coal sludge to polyamide reduces the time and temperature of the end of the thermal decomposition process (PA6: $638^{\circ} \mathrm{C} ; \mathrm{M}: 600^{\circ} \mathrm{C}$ ). Coal sludge can be treated as an energy fuel, which under the high-temperature process goes through specific stages: heating, moisture evaporation, devolatilisation and combustion of volatiles as well as char combustion [13]. The maximum DTG value is higher for polyamide than for coal sludge. The thermal decomposition of the polyamide $\left(369.0^{\circ} \mathrm{C}\right)$ starts at a higher temperature than the coal sludge $\left(325.0^{\circ} \mathrm{C}\right)$. In the case of polyamide, the maximum DSC peak has a lower value and takes place at a higher temperature $\left(476.4^{\circ} \mathrm{C} / 3.27 \mathrm{~mW} / \mathrm{mg}\right)$, compared to the coal sludge $\left(449.6^{\circ} \mathrm{C} / 6.3 \mathrm{~mW} / \mathrm{mg}\right)$. 


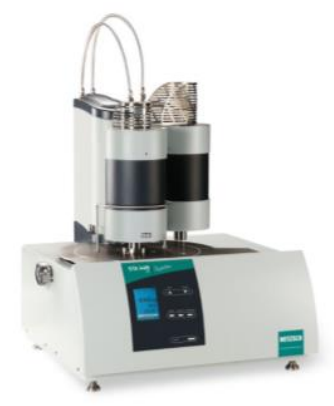

Fig. 2. STA 449 F3 Jupiter (Netzsch) apparatus [15]

Table 2. Analysis of measurements

\begin{tabular}{|c|c|c|c|}
\hline Material & DSC peaks & $\begin{array}{l}\text { Maximum DTG } \\
\text { value }\end{array}$ & $\begin{array}{l}\text { End of } \\
\text { process }\end{array}$ \\
\hline PA6 & $\begin{array}{l}222.8^{\circ} \mathrm{C} /-1.5 \mathrm{~mW} / \mathrm{mg} \\
369.0^{\circ} \mathrm{C} \\
427^{\circ} \mathrm{C} / 1.45 \mathrm{~mW} / \mathrm{mg} \\
451.3^{\circ} \mathrm{C} / 1.8 \mathrm{~mW} / \mathrm{mg} \\
\mathbf{4 7 6 . 4}^{\circ} \mathrm{C} / \mathbf{3 . 2 7} \mathbf{~ m W} / \mathbf{m g}\end{array}$ & $444.0^{\circ} \mathrm{C} / 13.3 \% / \mathrm{min}$. & $638^{\circ} \mathrm{C}$ \\
\hline PA6+1\%M & $\begin{array}{l}222^{\circ} \mathrm{C} /-1.47 \mathrm{~mW} / \mathrm{mg} \\
\frac{377.0^{\circ} \mathrm{C}}{\mathbf{4 7 3 . 4 ^ { \circ }} \mathrm{C} / \mathbf{2 . 9 7} \mathbf{~} \mathbf{W W} / \mathbf{m g}}\end{array}$ & $444.0^{\circ} \mathrm{C} / 15.0 \% / \mathrm{min}$. & $613^{\circ} \mathrm{C}$ \\
\hline PA6+3\%M & $\begin{array}{l}222^{\circ} \mathrm{C} /-0.67 \mathrm{~mW} / \mathrm{mg} \\
376.0^{\circ} \mathrm{C} \\
435.8^{\circ} \mathrm{C} / 4.8 \mathrm{~mW} / \mathrm{mg} \\
\mathbf{4 5 2 . 8}^{\circ} \mathrm{C} / 4.6 \mathrm{~mW} / \mathrm{mg}\end{array}$ & $445.0^{\circ} \mathrm{C} / 16.3 \% / \mathrm{min}$. & $612^{\circ} \mathrm{C}$ \\
\hline PA6+5\%M & 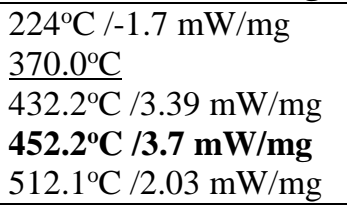 & $450.0^{\circ} \mathrm{C} / 18.9 \% / \mathrm{min}$. & $602^{\circ} \mathrm{C}$ \\
\hline $\mathrm{M}$ & $\frac{325.0^{\circ} \mathrm{C}}{449.6^{\circ} \mathrm{C} / 6.3 \mathrm{~mW} / \mathrm{mg}}$ & $450.0^{\circ} \mathrm{C} / 3.5 \% / \mathrm{min}$. & $600^{\circ} \mathrm{C}$ \\
\hline
\end{tabular}

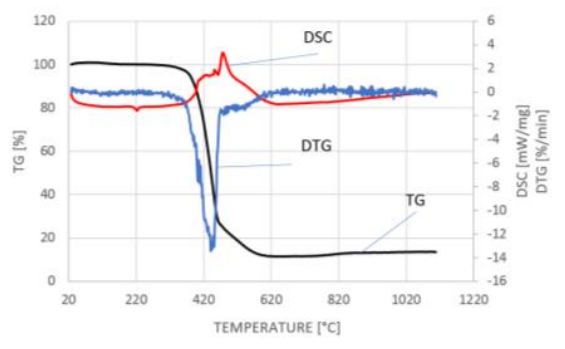

a) 
b)
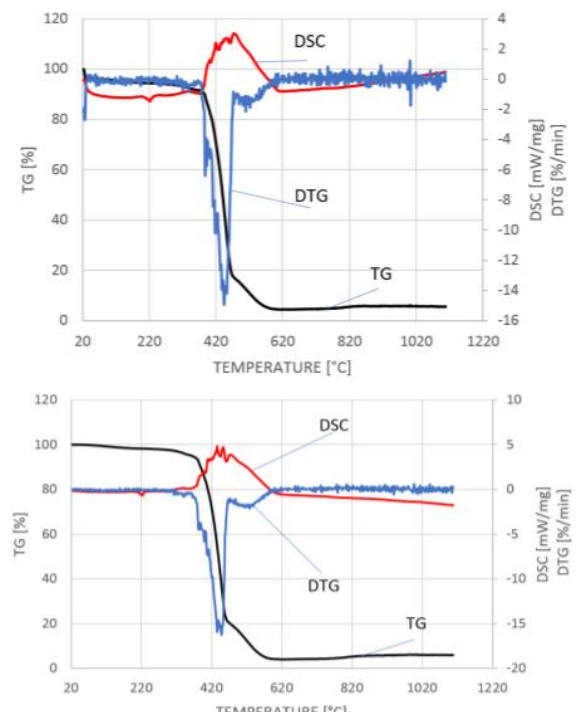

c)

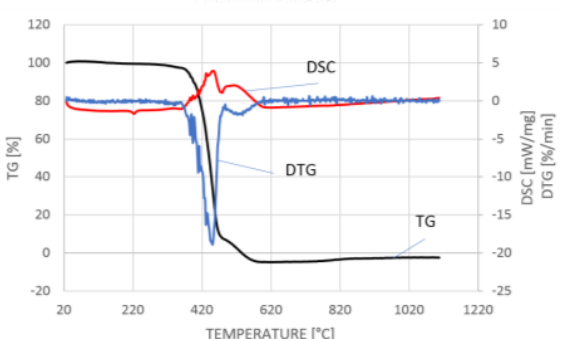

d)

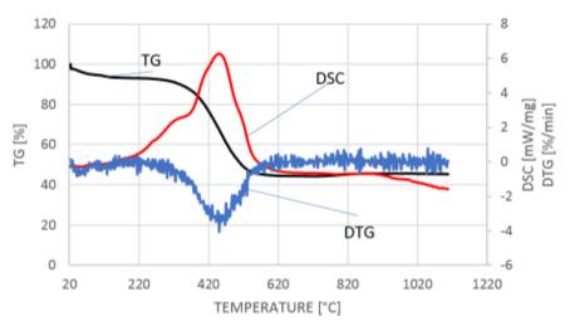

e)

Fig. 3. DSC/TG/DTG curves of: a) PA6 9 (polyamide), b) PA6+1\%M, c) PA6+3\%M, d) PA6+5\%M, e) $\mathrm{M}$ (coal sludge) 


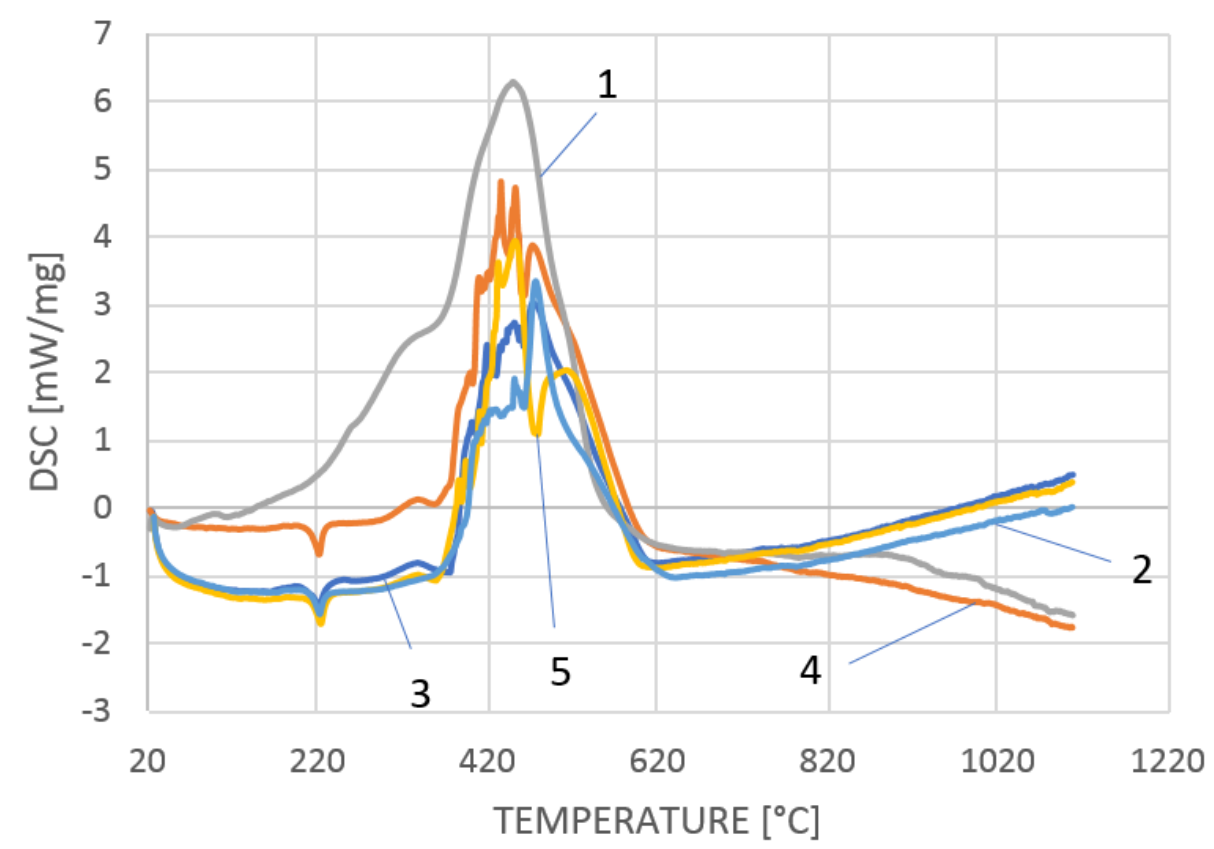

Fig. 4. DSC curves of samples; 1 - M (coal sludge), 2- PA6 9 (polyamide), 3 - PA6+1\%M, 4 - PA6+3\%M, 5 - PA6+5\%M

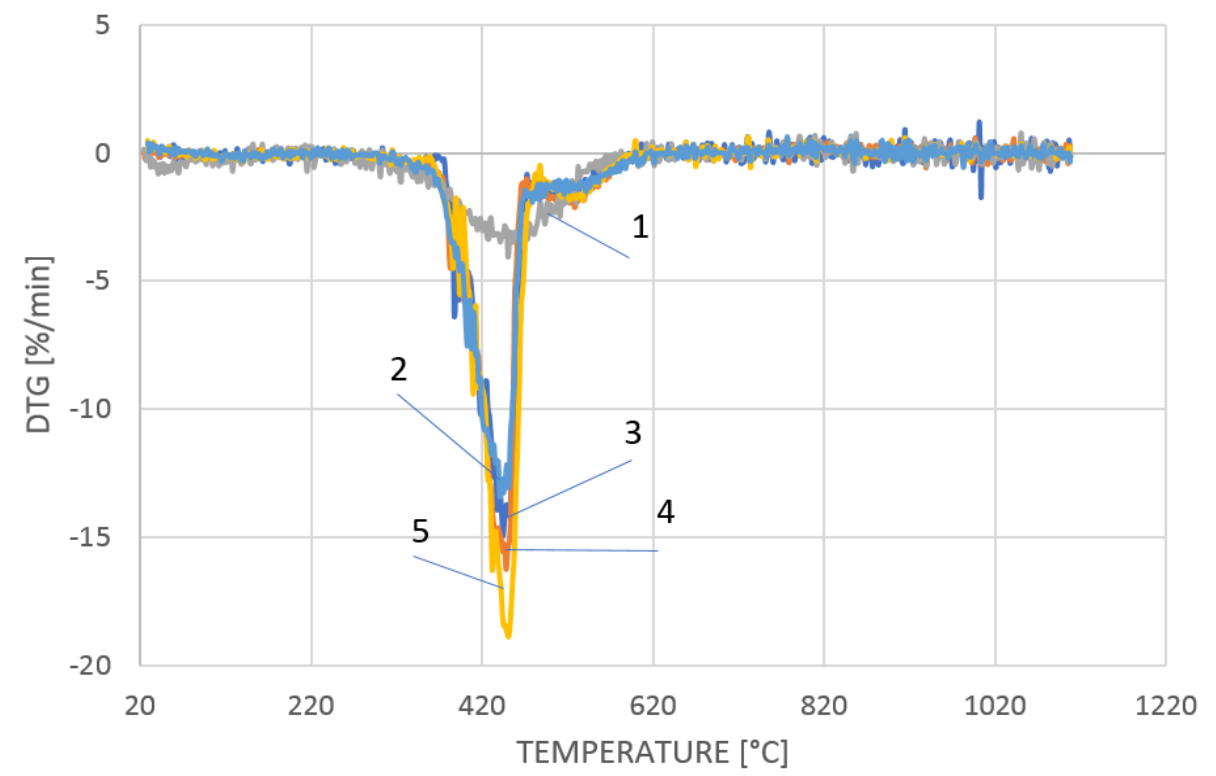

Fig. 5. DTG curves of samples; 1 - M (coal sludge), 2- PA6 9 (polyamide), 3 - PA6+1\%M, 4 - PA6+3\%M, 5 - PA6+5\%M 


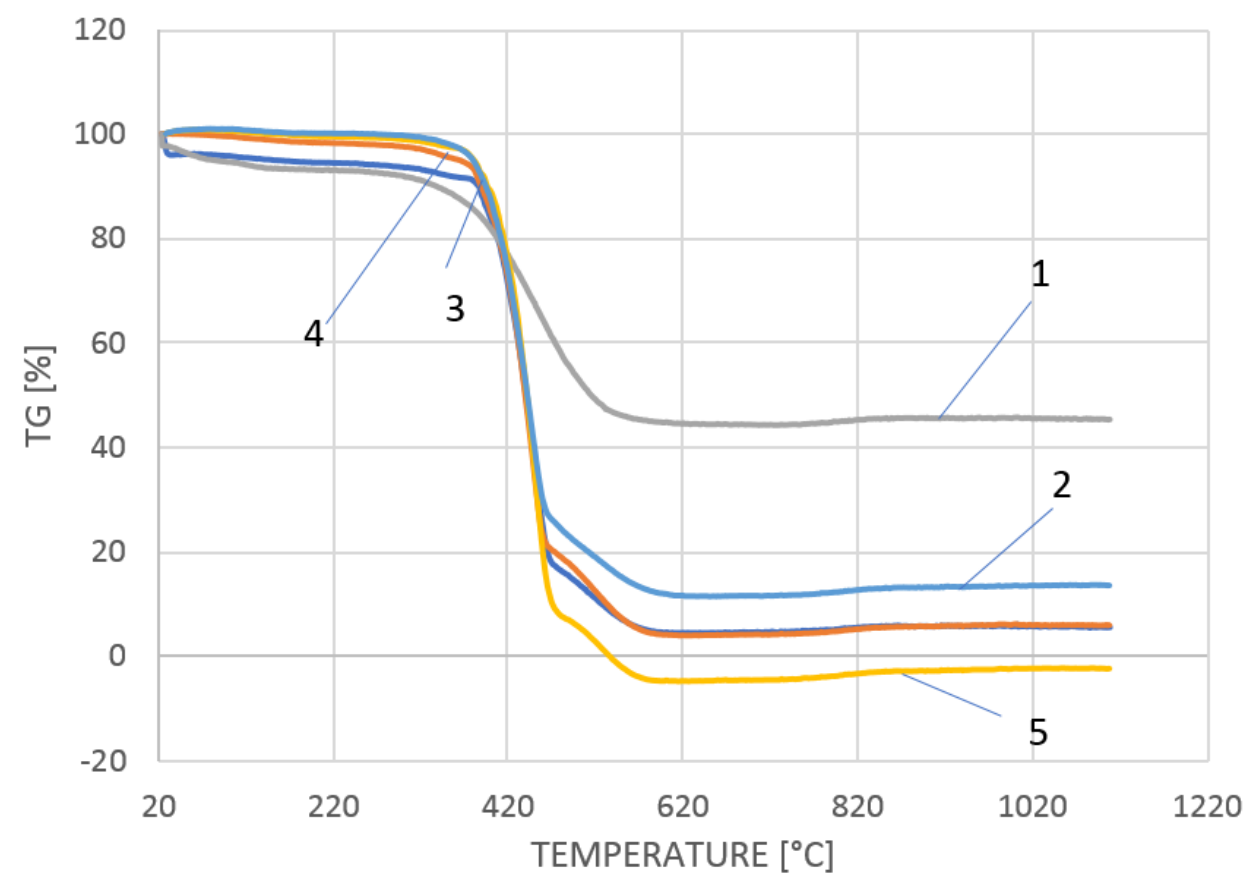

Fig. 6. TG curves of samples; 1 - M (coal sludge), 2- PA6 9 (polyamide), 3 - PA6+1\%M, 4 - PA6+3\%M, 5 - PA6+5\%M

\section{Conclusions}

1. In the case of polyamide and polyamide composites with coal sludge, DSC peaks are observed at a temperature of about $222^{\circ} \mathrm{C}$ (about $1.5 \mathrm{~mW} / \mathrm{mg}$ ), associated with the endothermic melting process.

2. The thermal decomposition of coal sludge takes place at a lower temperature than the decomposition of polyamide and the composites.

3. The addition of coal sludge to polyamide shortens the thermal decomposition time of the sample, compared to the polyamide.

4. The coal sludge achieves a maximum DTG value at a higher temperature, compared to the polyamide. The maximum DTG value for polyamide is higher than for coal sludge.

5. The coal sludge achieves a DSC peak $\left(449.6^{\circ} \mathrm{C} / 6.3 \mathrm{~mW} / \mathrm{mg}\right)$, at a lower temperature, compared to the polyamide $\left(476.4^{\circ} \mathrm{C} / 3.27 \mathrm{~mW} / \mathrm{mg}\right)$.

\section{References}

1. Singh S.B., Ray S.: Newly proposed yield criterion for residual stress and steady state creep in an anisotropic composite rotating disc, J. Mater. Process. Tech., 143144, 2003, 623-628.

2. Rosato D.V., Rosato M.G., Schott N.R.: Plastics Technology Handbook: Exeter, Momentum Press, 2011. 
3. Fazal A., Arif M.: Numerical prediction of plastic deformation and residual stresses induced by laser shock processing, J. Mater. Process. Tech. 136, 2003, 120-138.

4. T.D. Papathanasiou, M.R. Kamal: Filling of a Complex-Shaped Mold with a Viscoelastic Polymer. Part I: The Mathematical Model. Polymer Engineering and Science 33, 1993, 400-409.

5. A. Gnatowski, J. Koszkul: Investigations of the Influence of Compatibilizer and Filler Type on the Properties of Chosen Polymer Blends. Journal Material Processing Technology 162-163, 2005, 52-58.

6. Ehrenstein G.W.: Polymeric Materials, Hanser Publishers, Munich 2001, 1-12.

7. Pramoda K. P., Liu T.: Effect of moisture on the dynamic mechanical relaxation of polyamide-6/clay nanocomposites. J. Polym. Sci., Part B: Polym. Phys. 42, 10, 2004, 1823-1830.

8. Xie S., Zhang S., Wang F., Liu H., Yang M.: Influence of annealing treatment on the heat distortion temperature of nylon-6/montmorillonite nanocomposites, Polym. Eng. Sci., 45, 9, 2005, 1248-1253.

9. Gnatowski A.: Influence of the Polyvinylpyrrolidone Modification on Crystallines and Properties of Selected Thermoplastic Polymers. Journal of Polymer Engineering 27, 6-7, 2007, 507-524.

10. Kijo-Kleczkowska A.: Analysis of Coal with Coal-Mule and Biomass CoCombustion in Slurry Form. Archives of Mining Sciences 59, 2014, 347-366.

11. Kijo-Kleczkowska A., Otwinowski H.: Coal-Water Fuels Combustion in Fluidised Bed. Rynek Energii 6 (139), 2018, 92-97.

12. Kijo-Kleczkowska A.: Combustion of Coal-Mule Briquettes. Archives of Mining Sciences 58, 2013, 617-628.

13. Kijo-Kleczkowska A, Szumera M., Środa K.: Application of thermal analysis methods of in researches of fuels. Rynek Energii 5 (126), 2016, 85-94.

14. Kijo-Kleczkowska A, Szumera M., Środa K.: Metody analizy termicznej w badaniach paliw. Rynek Energii 4 (137), 2018, 38-45.

15. www.netzsch-thermal-analysis.com (with the consent of NETZSCH Analysing \& Testing ) 